\title{
CATCH AND SIZE OF BULLET AND FRIGATE TUNA CAUGHT BY USING DRIFTING GILLNET IN INDIAN OCEAN OF INDONESIA BASED AT CILACAP FISHING PORT
}

\author{
Agustinus Anung Widodo') and Fayakun Satria ${ }^{2)}$ \\ 1) Researcher in Research Center for Fisheries Management and Conservation (RCFMC), \\ 2) Research Institute for Fisheries Enhancement and Conservation (RIFEC). \\ Received May 23-2013; Received in revised form December 02-2013; Accepted December 06-2013
}

\begin{abstract}
Pelagic fishes such as bullet and frigate tuna in the Indian Ocean were caught in Indian Ocean of Indonesian jurisdiction using various fishing gears including, drifting gillnet and landed in various fishing port in along coastal of west Sumatera (Banda Aceh, Pariaman, Bungus/Padang and Painan) as well as south Java, Bali and Nusatenggara (Muarabaru/Jakarta, Pelabuhanratu, Cilacap, Kedonganan, Benoa). In Cilacap, tuna drifting gillnet fishery is fishing bullet and frigate tuna as by product. The current work describes the catch and size distribution of bullet tuna (Auxis rochei Risso, 1810) and frigate tuna (Auxis thazard Lacepède, 1800) caught by drifting gillnet based at Cilacap Fishing Port. Data and information obtained through catch monitoring, port sampling and landing report of Cilacap Fishing Port 2011 as well as from Capture Fisheries Statistics of Indonesia 2010. The catch estimation of bullet and frigate tuna on drifting gillnet fishery is about 3.220 and 47.346 tons respectively. The catch rate of drifting gillnets on the frigate tuna was 0.364 $\mathrm{mt} /$ trip in 2006 decreased to $0.054 \mathrm{mt} /$ trip in 2011 (decreased average 17\% per year). The catch rate of drifting gillnets on the bullet tuna was also decreased from $0.178 \mathrm{mt} / \mathrm{trip}$ in 2006 to $0.013 \mathrm{mt} /$ trip in 2011. The FL of bullet and frigate tuna ranged respectively between $16-39 \mathrm{~cm}$ and $25-46 \mathrm{~cm}$. Both species were mostly caught by drifting gillnet in adult size condition.
\end{abstract}

\section{KEYWORD: Catch and size distribution, bullet and frigate tuna, drifting gillnet, Indian Ocean, Cilacap fishing port.}

\section{INTRODUCTION}

Drifting gillnet was developed in Cilacap (Southern coastal of central Java) since ten years ago. The fishing ground of drifting gillnet based at Cilacap is in Indian Ocean. The main target of this fishing gear is tuna and tuna like including neritic tuna and sheerfish. Based on the 'Cilacap Fishing Port Annual Report of 2011', the number of drifting gillnetter based at Cilacap Fishing Port is 205 fleets. This number has increased significantly compared to that in 2010 when it was 165 fleets. The drifting gillnet was nylon multifilament with mesh size 5 inch and operated by wooden boat 20-30 GT. Each boat operates about 50-60 piece of drifting gillnet.

There are 4 species of neritic tuna and 2 species sheerfish under IOTC management i.e. longtail tuna (Thunnus tonggol), frigate tuna (Auxis thazard), bullet tuna (Auxis rochel), kawakawa (Euthynnus affinis), narrow-barred Spanish mackerel (Scomberomorus commerson) and Indo-Pacific king mackerel (Scomberomorus guttatus) (Herrera, at al., 2009). National Fisheries Statistic of Indonesia (DGCF, 2011) noted that the six species were caught in Western Sumatera and Southern Java Indian Ocean. Generally neritic tuna and sheerfish are part of the catch of purse seine, drifting gillnet, hand lining and trolling lines gear.
Statistic of Marine Fisheries of Cilacap Fishing Port (2012) reported that mostly of bullet tuna (Auxis rochei Risso, 1810) and frigate tuna (Auxis thazard Lacepède, 1800) caught by drifting gillnet. Total production of the drifting gillnets fisheries landed in Cilacap Fishing Port on 2012 reached $101 \mathrm{mt}$ and 6 $\mathrm{mt}$ for bullet and frigate tuna respectively. The production drifting gillnet contributed about $0.20 \%$ and $0.26 \%$ of total catch of bullet and frigate tuna from Indian Ocean West of Sumatera and South Java, Bali and Nusa Tenggara.

Availability the information of catch by species, gear and fishing ground as well as the size of fish was important aspects in the fish stock assessment work. This paper describes the catch and size distribution of bullet tuna (Auxis rochei Risso, 1810) and frigate tuna (Auxis thazard Lacepède, 1800) caught by drifting gillnet in the Indian Ocean based at Cilacap Fishing Port, Central Java.

\section{MATERIALS AND METHODS}

The primary data were gathered in 2010 from catch monitoring and landing report of drifting gillnetters operated in Indian Ocean based at Cilacap Fishing Port where the field survey was conducted in 2011. The data covered fishery and fish biology aspects. Fishery data consisted of fishing operational and

Corresponding author:

Researcher in Research Center for Fisheries Management and Conservation

JI. Pasir Putih II, East Ancol-Jakarta 14430 
catch (effort data and trip catch, the biological data consisted of species and size (fork length-FL). The samplings were conducted in April, August and December, it was done by two enumerators.

The enumerator did the record of data/information including vessel name, number of piece of net, trip duration, main fishing ground) and total catch (weight) for all drifting gillnetter arriving in port after fishing. Those data and were information obtained from the skippers through interview and available log book. The biological aspects of data were obtained through the random sampling of catch. Number of sample was three boxes (about 30-50 kg/box) taken on the beginning, middle and the end times of catch unloading. The secondary data were noted from National Fisheries Statistics 2005-2010 published by DGCF and Annual Report of Cilacap Fishing Port for the period of 2005-2011.

\section{RESULTS}

\section{Fishery (Fleet, Gear and Season)}

Mostly drifting gillnet fleets based at Cilacap Fishing Port are fishing in Indian Ocean within Indonesian Fisheries Management Area-FMA573. The number of registered fishing fleet based at Cilacap Fishing Port in 2011 was 892 with detail of 299 tuna longliners, 138 set gillnetters, 205 drifting gillnetters, 181 trammel netters, 98 monofilament gillnetters, 42 bottom Danish seiners, 7 pelagic Danish seiners, 7 portable trappers and 3 lift netters (Table 1). The 205 drifting gillnetter were $23 \%$ of total fleet and only 127 active gillnetters noted in 2011. In general the number of gillnetter increased every year about $5.7 \%$ in average.

Table 1. Fishing fleet structure based at Cilacap Fishing Port in 2005 to 2011.

\begin{tabular}{lrrr}
\hline Fishing Fleet & 2005 & $\mathbf{2 0 0 6}$ & $\mathbf{2 0 0 7}$ \\
\hline Tuna Long Liner & 161 & 128 & 156 \\
Drifting Gillnetter & 63 & 196 & 184 \\
Set Gillnetter & 84 & 103 & 105 \\
Trammel Netter & 327 & 199 & 115 \\
Pelagic Danish Seine & 6 & 8 & 10 \\
Botton Danish Seine & 39 & 40 & 50 \\
Portablel Trapper & 0 & 0 & 64 \\
Lift Netter & 0 & 0 & 0 \\
\hline
\end{tabular}

Drifting gillnet fleets were wooden boat size 10-30 GT with the main engine 120-160 HP and generator engine 24-30 HP. Fish hold of the boats is not equipped with refrigeration machine, the freshness of catch is preserved with the ice. Drifting gillnet fleets are generally equipped by compass and GPS for the navigation purpose and SSB radio for communication. Number of crew each boat about 12-14 persons. Fishing trip duration is 18-22 days per trip with the effective days 16-20. Figure 1 presents size (GT) structure of active gillnetters based at Cilacap Fishing Port in 2011.

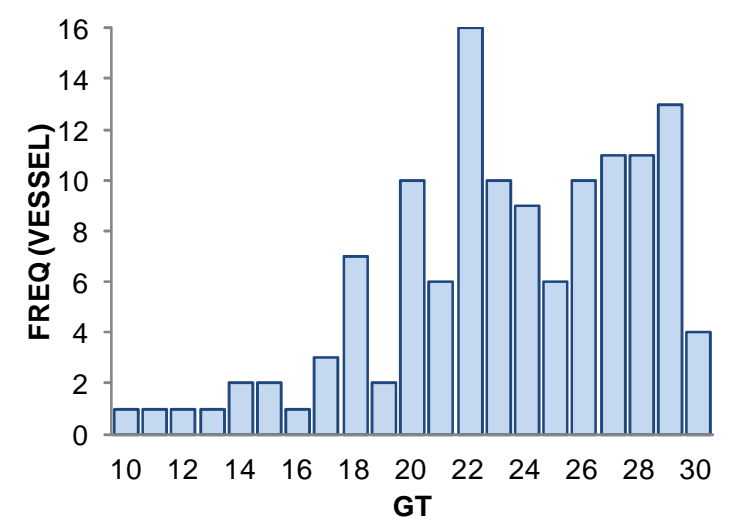

Figure 1. Size (GT) structure of 127 active gillnetters based at Cilacap Fishing Port 2011.

The drifting gillnet is a wall of fine, large-meshed synthetic netting with a series of floats attached in the corks line at the top and a series of weights (leads or concrete) at the bottom to maintain it vertical in midwater, in general, not far below the surface. It is normally set at dusk and hauled at dawn or in the morning. The length of drifting gillnets deployed by fishermen targeting tuna or other large pelagic fish such as swordfish, is commonly several kilometers whereas the height ranges from 18 to $30 \mathrm{~m}$. Widodo (2011) noted that one piece of drifting gillnet in Cilacap has length $38-40 \mathrm{~m}$ and height $18-20 \mathrm{~m}$. Webbing material is nylon multifilament type d-21 and mesh size 5 inch. Floats are synthetic rubber type Y-15 as much as 6 floats and 4 weights from concrete $0.5 \mathrm{~kg}$ each weight per piece of drifting gillnet. Each piece of gillnet is equipped 2 plastic buoy $\varnothing 30 \mathrm{~cm}$ and buoy line $6 \mathrm{~m}$ in length for keeping the position of gillnet about 5-6 $\mathrm{m}$ below the sea surface. Generally, a drifting gillnet fleet operates 50-60 piece gillnets or about 1.5-2.5 kilometer in total length.

The fishing season represented by number of fish landing, the number of bullet and frigate landing in 2011 fluctuated between months, with the highest landing was experienced in December (Figure 3). During this month drifting gillnet was mostly fished in offshore waters where sea condition was very calm. 


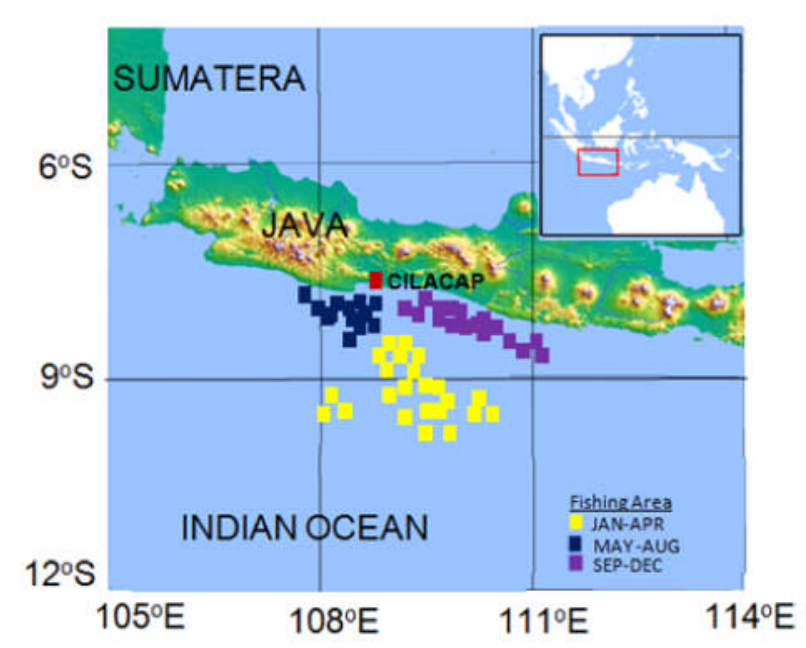

Figure 2. Drifting gillnet fishing area based at Cilacap Fishing Port in 2011.

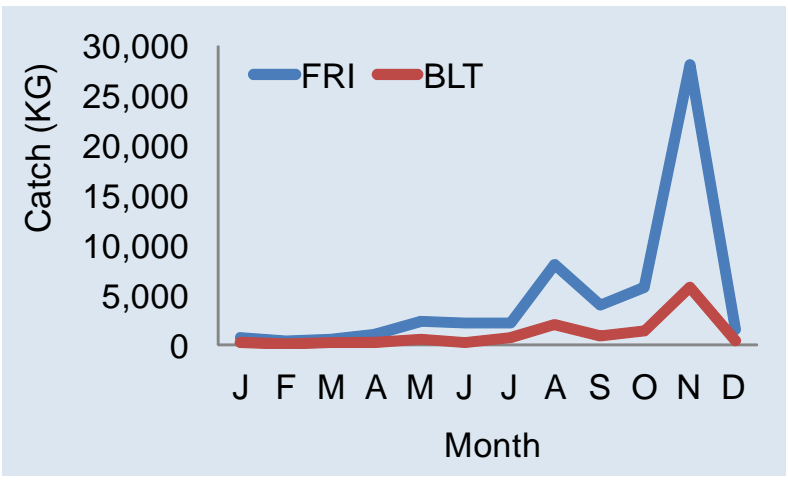

Figure 3. The fluctuation of bullet and frigate tuna catch on drifting gillnet fishery based at Cilacap Fishing Port during 2011.

\section{Catch}

In Indonesian Fisheries National Statistic is reported that annual catch of the two main species of neritic tuna such as bullet and frigate tuna from Indian Ocean which composed of Western Sumatera, Southern Java and Southern Bali-NTT. The catch in 2010 is estimated 2,445 and 47,113 mt for bullet and frigate tuna respectively as described in Table 2 . Compared to the previous year annual catch, annual catch of bullet in 2010 has experienced significant increasing. Since the past six years, the average annual catch of frigate tuna annual catch increased about $76 \%$ per year. While the average of bullet tuna annual catches was experienced steady decreasing reaching about $34 \%$ per year. The catch of frigate tuna from Indonesian Indian Ocean shared about 35\% to the national level of frigate tuna total catch estimation $(132,772 \mathrm{mt})$. Whilst the catch of bullet tuna contributed about $66 \%$ to the national level of bullet tuna total catch estimation $(3,696 \mathrm{mt})$ as described in Table 3.

The catch per unit effort (CPUE) of drifting gillnets on frigate and bullet tuna based at Cilacap Fishing Port is represented by its catch rate. Result of catch monitoring during six past year (2006-2011) shows that the catch rate of drifting gillnets on both species frigate and bullet tuna decreased year by year. As described in Table 4 that the catch rate of drifting gillnets on the frigate tuna was $0.364 \mathrm{mt} /$ trip in 2006, this value decreased to $0.054 \mathrm{mt} /$ trip in 2011 (decreasing average of $17 \%$ per year). The situation on the resource of bullet tuna is also similar to the frigate tuna. The catch rate of drifting gillnets on the bullet tuna was also decreased from $0.178 \mathrm{mt} /$ trip in 2006 to $0.013 \mathrm{mt} /$ trip in 2011.

In term of catch composition, drifting gillnet fish landing is dominated by skipjack tuna i.e. $68.5 \%$ from total $3358.878 \mathrm{mt}$, whilst frigate and bullet tuna were only $1.6 \%$ and $0.4 \%$ respectively (Figure 3 ) and the detail of species caught by drifting gillnet is presented in Table 5 which was at least 50 species identified during catch monitoring in 2011.

\section{Fish Size}

The size (fork length-FL) both species frigate and bullet tuna caught by gillnet mesh size 5 inch varied with month and fishing area as presented below:

\section{a. Bullet Tuna}

The size (FL) of bullet tuna caught on April, August and December 2011 ranged between 16-39 cm with mode at $36 \mathrm{~cm}, 36 \mathrm{~cm}$ and $35 \mathrm{~cm}$ respectively (Figure $4)$. It is compared to the result of onboard observation in 2008-2010 (Widodo et al., 2011) that the size of bullet tuna caught in 2011 was relative smaller. The smallest size of bullet tuna caught in 2008 was ranged $24-45 \mathrm{~cm}$ with mode at $42 \mathrm{~cm}$.

\section{b. Frigate Tuna}

In April, August and December 2011 the size (fork length- $F L$ ) distribution of frigate tuna caught ranged $25-46 \mathrm{~cm}$ with the mode $32 \mathrm{~cm}, 33 \mathrm{~cm}$ and $33 \mathrm{~cm}$ respectively (Figure 5). The size was smaller than the common size frigate tuna i.e. $60 \mathrm{~cm}$ that as mentioned by Figueiredo et al. (2002). 
Table 2 The estimate of catch of neritic tuna and sheerfish landing in Western Sumatera, Southern Java and Southern Bali-Nusatenggara 2005-2010.

\begin{tabular}{|c|c|c|c|c|c|c|c|}
\hline \multirow{2}{*}{ Year } & \multirow{2}{*}{ Landing Places } & \multicolumn{6}{|c|}{ Production by Species (TON) } \\
\hline & & FRI & BLT & LOT & KAW & COM & GUT \\
\hline \multirow[t]{4}{*}{2010} & West Sumatera & 19,516 & 2,296 & 14,435 & 13,840 & 7,923 & 7,444 \\
\hline & South Java & 149 & 121 & 516 & 15,217 & 2,466 & 1 \\
\hline & Bali-Nusatenggara & 27,448 & 28 & 3,995 & 10,818 & 4,646 & 268 \\
\hline & Sub Total & 47,113 & 2,445 & 18,946 & 39,875 & 15,035 & 7,713 \\
\hline \multirow[t]{3}{*}{2009} & West Sumatera & 16,691 & 2,869 & 12,925 & 7,507 & 2,358 & 7,916 \\
\hline & South Java & 2,891 & 897 & 361 & 19,514 & 2,358 & 5 \\
\hline & Sub Total & 19,582 & 3,766 & 13,286 & 27,021 & 4,716 & 7,921 \\
\hline \multirow[t]{3}{*}{2008} & West Sumatera & 19,251 & 936 & 8,183 & 29,380 & 8,010 & 7,351 \\
\hline & South Java & 4,202 & 982 & 476 & 18,417 & 30 & 2,571 \\
\hline & Sub Total & 23,453 & 1,918 & 8,659 & 47,707 & 8,040 & 9,922 \\
\hline \multirow[t]{3}{*}{2007} & West Sumatera & 20,733 & 10 & 11,622 & 8,599 & 7,676 & 9,220 \\
\hline & South Java & 5,439 & 3,304 & 374 & 15,124 & 11,175 & 64 \\
\hline & Sub Total & 26,172 & 3,314 & 11,996 & 23,723 & 18,851 & 9,284 \\
\hline \multirow[t]{3}{*}{2006} & West Sumatera & 4,460 & 3 & 6,251 & 16,771 & 6,737 & 4,488 \\
\hline & South Java & 13,257 & 530 & 3,626 & 228 & 2,885 & 45 \\
\hline & Sub Total & 17,717 & 533 & 9,877 & 16,999 & 9,622 & 4,533 \\
\hline \multirow[t]{3}{*}{2005} & West Sumatera & 3,929 & 3 & 3,057 & 15,038 & 4,456 & 2,992 \\
\hline & South Java & 6,912 & 0 & 1,682 & 2,108 & 2,358 & 36 \\
\hline & Sub Total & 10,841 & 3 & 4,739 & 17,146 & 6,814 & 3,028 \\
\hline \multirow[t]{4}{*}{2004} & West Sumatera & 3,237 & 6 & 11,216 & 9,963 & 4,555 & 3,480 \\
\hline & South Java & 31 & 0 & 8,127 & 6,068 & 2,737 & 1 \\
\hline & Sub To tal & 3,268 & 6 & 19,343 & 16,031 & 7,292 & 3,481 \\
\hline & & & tle Tuna & & & COM & GUT \\
\hline \multirow[t]{3}{*}{2003} & West Sumatera & & 26,312 & & & 6,147 & 6,034 \\
\hline & South Java & & 10,009 & & & 2,775 & 29 \\
\hline & Sub Total & & 36,321 & & & 8,922 & 6,057 \\
\hline \multirow[t]{3}{*}{2002} & West Sumatera & & 18,210 & & & 4,315 & 3,745 \\
\hline & South Java & & 26,609 & & & 3,855 & 24 \\
\hline & Sub Total & & 44,819 & & & 8,170 & 3,769 \\
\hline \multirow[t]{3}{*}{2001} & West Sumatera & & 22,409 & & & 6,522 & 4,471 \\
\hline & South Java & & 6,875 & & & 3,160 & 105 \\
\hline & Sub Total & & 29,284 & & & 9,682 & 4,576 \\
\hline
\end{tabular}

Source: Capture Fisheries Statistics of Indonesia 2010 (DGCF, 2011).

Note: $\mathrm{FRl}=$ frigate tuna, BLT=bullet tuna, LOT=longtail tuna, KAW= kawa-kawa, COM=narrow-

barred Spanish mackerel and GUT=Indo-Pacific king mackerel.

Table 3. The national level and in Indonesian Indian waters Ocean catch of frigate and bullet tuna 2010.

\begin{tabular}{lrr}
\hline \multirow{2}{*}{ Landing Places } & \multicolumn{2}{c}{ Production (ton) } \\
\cline { 2 - 3 } & \multicolumn{1}{c}{ FRI } & \multicolumn{1}{c}{ BL T } \\
\hline NA TIONAL & $\mathbf{1 3 2 , 7 3 3}$ & $\mathbf{3 , 6 9 6}$ \\
IND IAN OCEAN & $\mathbf{4 7 , 1 1 3}$ & $\mathbf{2 , 4 4 5}$ \\
Sub Total & & \\
West Sumatera & $\mathbf{1 9 , 5 1 6}$ & $\mathbf{2 , 2 9 6}$ \\
Aceh (Aceh) & 4,169 & 1,835 \\
Sumatera Utara (North Sum a1 & 1,528 & - \\
Sumatera Barat (West Sumat & 12,102 & 399 \\
Bengkulu (Bengkulu) & 1,645 & 36 \\
Lampung (Lampung) & 72 & 26 \\
Sub Total & $\mathbf{1 4 9}$ & $\mathbf{1 2 1}$ \\
South of Java & 0 & 0 \\
Banten (Banten) & 5 & 120 \\
Jawa Barat (West Java) & 25 & 1 \\
Jawa Tengah (Central Java) & 119 & 0 \\
DI Yogyakarta (Yogyakarta) & 0 & 0 \\
Jawa Timur (East Java) & & \\
Sub Total & $\mathbf{2 7 , 4 4 8}$ & $\mathbf{2 8}$ \\
South of Bali-Nusatenggara & $\mathbf{2 7}$ & 0 \\
Bali (Bali) & 15,475 & 27 \\
NTB (West Nusatenggara) & 922 & 1 \\
NTT (East Nusatenggara) & 11,051 &
\end{tabular}

Source: Capture Fisheries Statistics of Indonesia 2010 (DGCF, 2011).
Table 4. Catch rate of drifting gillnets to frigate and bullet tuna base at Cilacap Fishing Port year 2006-2011.

\begin{tabular}{|c|c|c|c|c|c|c|c|}
\hline \multirow[b]{2}{*}{ Year } & \multirow{2}{*}{$\begin{array}{l}\text { Registere } \\
\text { d Vessel }\end{array}$} & \multirow{2}{*}{$\begin{array}{l}\text { Active } \\
\text { Vessel }\end{array}$} & \multirow{2}{*}{$\begin{array}{l}\text { Number } \\
\text { of Trip }\end{array}$} & \multicolumn{2}{|c|}{ Catch (TON) } & \multicolumn{2}{|c|}{ Catch Rate (TON/Trip) } \\
\hline & & & & $\begin{array}{r}\text { Frigate } \\
\text { Tuna (FRI) }\end{array}$ & $\begin{array}{r}\text { Bullet Tuna } \\
(B L T)\end{array}$ & $\begin{array}{c}\text { Frigate } \\
\text { Tuna (FRI) }\end{array}$ & $\begin{array}{l}\text { Bullet Tuna } \\
\quad(B L T)\end{array}$ \\
\hline 2006 & 63 & 61 & 427 & 270.646 & 75.925 & 0.634 & 0.178 \\
\hline 2007 & 196 & 144 & 1008 & 160.252 & 88.2 & 0.159 & 0.088 \\
\hline 2008 & 184 & 131 & 1279 & 232.558 & 11.440 & 0.182 & 0.009 \\
\hline 2009 & 183 & 102 & 603 & 69.050 & 48.000 & 0.115 & 0.080 \\
\hline 2010 & 165 & 98 & 492 & 42.600 & 16.000 & 0.087 & 0.033 \\
\hline 2011 & 205 & 127 & 1054 & 57.346 & 13.22 & 0.054 & 0.013 \\
\hline
\end{tabular}

(Anonymous. 2006-2011)

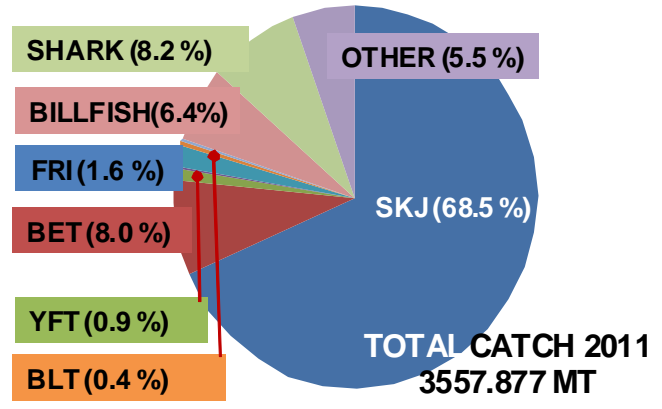

Figure 3. Catch composition of drifting gillnets based at Cilacap Fishing Port. 
Table 5. The catch compositions of drifting gillnet based at Cilacap Fishing Port.

\begin{tabular}{|c|c|c|c|c|c|c|c|}
\hline \multirow{2}{*}{\multicolumn{2}{|c|}{ SPECIES }} & \multicolumn{6}{|c|}{ CAICH(ION) } \\
\hline & & \multirow[t]{2}{*}{2006} & \multirow[t]{2}{*}{2007} & \multirow[t]{2}{*}{2008} & \multirow[t]{2}{*}{2009} & \multirow[t]{2}{*}{2010} & \multirow[t]{2}{*}{2011} \\
\hline Lokal Name & Common Name & & & & & & \\
\hline \multicolumn{8}{|l|}{ TUNA } \\
\hline Cakalang & Skipjacktuna & 4650.960 & 3265.375 & 2240.190 & 1835.674 & 350.681 & 2435.895 \\
\hline Tuna Mata Besar & Bigeye Tuna & 136.131 & 101.54 & 401.8166 & 894.94302 & 378.15539 & 286.31396 \\
\hline Madidihang & Yellowf in Tuna & 5.472 & 6.814 & 12.96723 & 76.03145 & 100.78909 & 32.49647 \\
\hline Albakor & Albacore & 0.035 & 0.072 & 3.065 & 5.392 & 2.696 & 9.2708 \\
\hline \multicolumn{8}{|l|}{ NERIT IC T UNA } \\
\hline $\begin{array}{l}\text { Tongkol Lurik } \\
\text { Tongkol Lisong }\end{array}$ & $\begin{array}{l}\text { Frigate Tuna } \\
\text { Bullet Tuna }\end{array}$ & $\begin{array}{r}270.646 \\
75.925\end{array}$ & $\begin{array}{r}160.252 \\
88.82\end{array}$ & $\begin{array}{r}232.558 \\
11.440\end{array}$ & $\begin{array}{r}6.905 \\
48.000\end{array}$ & $\begin{array}{r}1.260 \\
16.000\end{array}$ & $\begin{array}{r}57.346 \\
13.22\end{array}$ \\
\hline \multicolumn{8}{|l|}{ SHEERFISH } \\
\hline Tenggiri & Narrow Barred Spanis h Mackerel & 0.681 & 5.287 & 9.747 & 10.397 & 5.118 & 6.635 \\
\hline \multicolumn{8}{|l|}{ BILLFISH } \\
\hline Ikan Pedang & Swordfish & 3.425 & 9.5279 & 27.329 & 24.187 & 24.514 & 26.68157 \\
\hline Setuhuk hitam & Black Marlin & 70.378 & 86.832 & 117.095 & 109.777 & 21.448 & 89.98505 \\
\hline Setuhuk loreng & Indo Pacific Blue Marlin & 5.642 & 8.095 & 13.259 & 16.034 & 3.659 & 9.5493 \\
\hline Setuhuk putih & Striped Marlin & 31.110 & 57.241 & 81.712 & 41.106 & 15.975 & 44.78394 \\
\hline Layaran & Sailfish & 38.707 & 37.295 & 28.358 & 64.845 & 8.652 & 56.60665 \\
\hline Ikan Tumbuk & Shortbill Spearfish & 0.110 & 0.436 & 0.742 & 0.536 & 0.063 & 0.071 \\
\hline \multicolumn{8}{|l|}{ SHARK } \\
\hline Cucut Tikusan & Smallto oth Thressher Shark & 120.423 & 83.556 & 85.019 & 63.924 & 11.669 & 108.4796 \\
\hline Cucut Pahitan & Bigeyed Thresher Shark & 63.614 & 11.52 & 29.894 & 15.411 & 2.250 & 45.118 \\
\hline Cucut Lanyam Super & Spottail Shark & 4.836 & 4.718 & 7.529 & 0.672 & 0.190 & 1.2 \\
\hline Cucut Lanjaman & Silky Shark & 1.702 & 4.258 & 3.246 & 4.515 & 3.618 & 4.782 \\
\hline Cucut Selendang & Blue Shark & 6.153 & 3.447 & 3.291 & 0.673 & 0.624 & 0.901 \\
\hline Cucut Cakilan & Shortf in Mako Shark & 4.156 & 4.709 & 0.000 & 3.714 & 1.183 & 6.725 \\
\hline Cucut Cakilan Air & Long fin Mako Shark & 0 & 0 & 0 & 0 & 0 & 0.592 \\
\hline Cucut Macan (Cucut Buas) & Tiger shark & 0.436 & 0.57 & 0.000 & 0 & 0 & 0.077 \\
\hline Cucut Koboy & Oceanic Whitetip Shark & 0.079 & 0.195 & 0.185 & 0.127 & 0 & 0.211 \\
\hline Cucut Botol & Crocodille Shark & 0.079 & 0 & 0.953 & 0 & 0 & 0.394 \\
\hline Cucut Caping & Scalloped Hammerhead Shark & 7.426 & 5.417 & 6.648 & 2.573 & 0.680 & 0 \\
\hline Cucut Botol & Crocodille Shark & 0 & 0.262 & 0 & 1.715 & 0.010 & 0 \\
\hline Cucut Kapukan & Sharpnose Sevengill Shark & 1.172 & 0 & 0 & 0 & 0 & 0 \\
\hline Cucut Isabela & Westem Angel Shark & 2.063 & 0 & 0.086 & 0 & 0 & 0 \\
\hline $\begin{array}{l}\text { Cucut Londer } \\
\text { RAYS }\end{array}$ & Gummy Shark & 0.430 & 0 & 0 & 0 & 0 & 6.644 \\
\hline Pari Plampangan (Pari Hantu) & Manta Ray & 51.474 & 82.698 & 65.353 & 71.199 & 56.375 & 110.3099 \\
\hline Pari Kelapa & Cowtail Ray & 2.404 & 0 & 0 & 0 & 0 & 0 \\
\hline Pari Bluju & Mo bula Tarapacana & 0 & 0 & 1.860 & 3.553 & 4.411 & 5.576 \\
\hline Pari Kasab & Manta birostris & 0 & 0 & 0.000 & 3.242 & 0.411 & 1.703 \\
\hline \multicolumn{8}{|l|}{ OTHER } \\
\hline Lemadang & Common Dolphinfish & 6.698 & 17.391 & 26.029 & 24.154 & 19.345 & 42.582 \\
\hline Ikan Setan & Escoler & 0.187 & 0.47 & 4.873 & 0 & 0 & 8.789 \\
\hline Kakap hitam & Triple tail & 4.586 & 5.4819 & 13.418 & 15.488 & 11.097 & 23.369 \\
\hline Sunglir & Rainbow runner & 0.131 & 0.051 & 1.825 & 0.578 & 4.582 & 0.375 \\
\hline Cumi-Cumi & Squid & 31.460 & 77.738 & 134.950 & 95.684 & 13.506 & 114.535 \\
\hline Ikan Kempar pati & Mo onfish & 0.330 & 0 & 0.480 & 0 & 0.000 & 0 \\
\hline Kakak Tua (Etong) & White Spotted Trigerfish & 0.709 & 0.871 & 0.717 & 3.184 & 10.678 & 2.2555 \\
\hline Jahan (Manyung) & Giant Catfish & 27.906 & 9.638 & 0.000 & 0.000 & 0 & 0 \\
\hline Ikan Sebelah (Ikan Pihi) & Indian halibut & 2.565 & 0 & 0.000 & 0 & 0 & 0 \\
\hline Gogokan & Black Jew & 5.112 & 0 & 0.240 & 0 & 0 & 0 \\
\hline Gerok & Barret Gruntel & 0.455 & 0 & 0 & 0 & 0 & 0 \\
\hline Kuwe & Bigeye Trevally & 0.518 & 0 & 0.640 & 0 & 0 & 0 \\
\hline Tetengkek & Finny Scad & 0.280 & 0 & 0 & 0 & 0 & 0 \\
\hline Patilan & Dog Fish & 5.705 & 0 & 0 & 0 & 0 & 0 \\
\hline Casper & Angel Fish & 0 & 0.455 & 4.211 & 1.915 & 0.116 & 4.377 \\
\hline Slengseng & Slimy Mackerel & 0 & 4.232 & 2.000 & 0 & 0.000 & 0 \\
\hline Layur & Hair Tail & 0 & 0.165 & 3.101 & 0.040 & 0 & 0 \\
\hline Opah & - & 0 & 0 & 0.214 & 0.065 & 0 & 0.028 \\
\hline Gindara (Ikan Setan) & Escoler & 0 & 0 & 0 & 5.095 & 4.225 & 0 \\
\hline
\end{tabular}



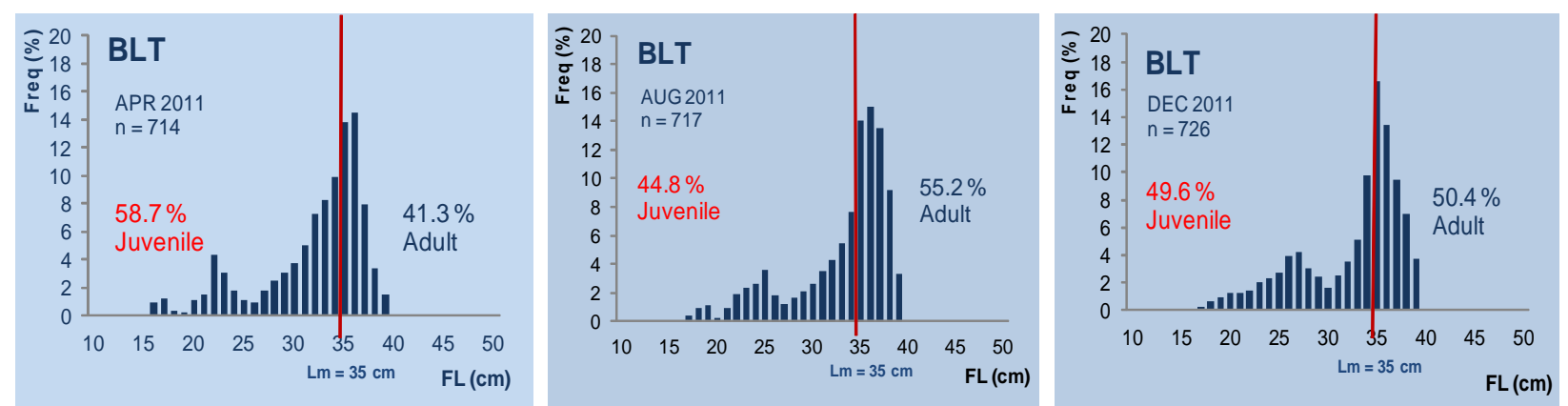

Figure 4. Size (FL) distribution of bullet tuna caught by drifting gillnets based at Cilacap Fishing Port in 2011.
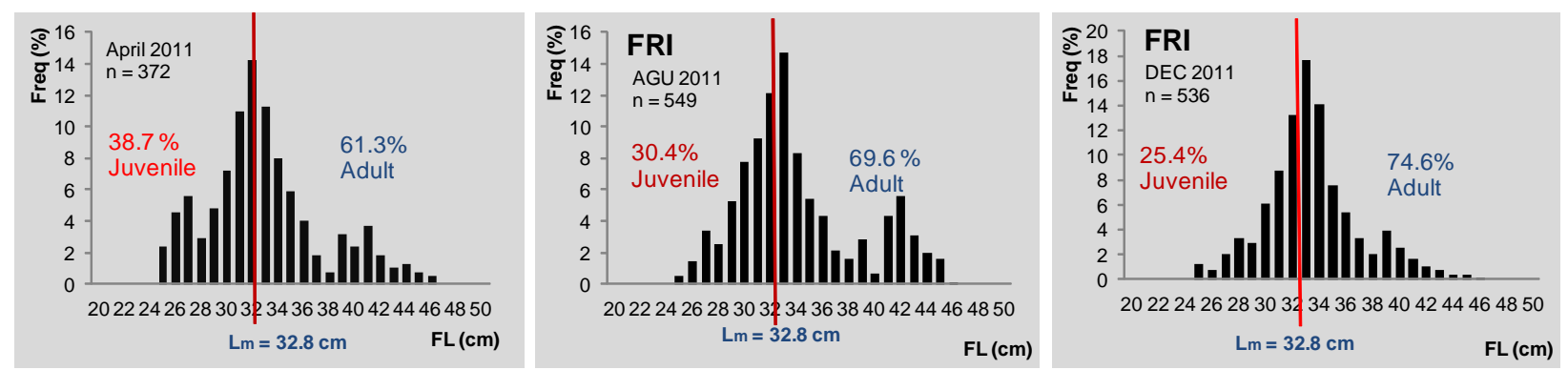

Figure 5. Size (FL) distribution of frigate tuna caught by drifting gillnets based at Cilacap Fishing Port in 2011.

\section{DISCUSSION}

\section{Catch}

Frigate and bullet tuna was species that mostly spend in inshore water, but they are probably cosmopolitan in warm waters; it is an epipelagic, neritic as well as oceanic species (Anonymous., 2006). Drifting gillnet based at Cilacap targets tuna and tuna like, whereas neritic tuna (frigate and bullet tuna) caught as by product. Catch rate of the frigate tuna was $0.364 \mathrm{mt} /$ trip in 2006, this value decreased to $0.054 \mathrm{mt} /$ trip in 2011 (decreasing average of $17 \%$ per year). The situation on the resource of bullet tuna is also similar to the frigate tuna. The catch rate of drifting gillnets on the bullet tuna was also decreased from $0.178 \mathrm{mt} /$ trip in 2006 to $0.013 \mathrm{mt} /$ trip in 2011 .

The result of research was in line with the behavior of bullet tuna. The bullet tuna is an epipelagic, neritic as well as oceanic species with strong schooling behavior.

Widodo (2011) noted that based on onboard observation conducted in 2008, 2009 and 2010 the drifting gillnet fleets based at Cilacap have similar fishing ground pattern in those years. In April they operate in the offshore waters, whereas in July and October they operate in the inshore waters. In 2011, the situation was relatively similar with the previous year. The fishing position of drifting gillnets fleets in 2011 ranged $7.0^{\circ}-11.0^{\circ} \mathrm{S}$ and $107.0^{\circ}-111.0^{\circ} \mathrm{E}$ (Figure 2). Since 2010 drifting gillnets fisheries experienced fishing pressure by the operation of purse seiners that are fishing in the drifting gillnet fishing ground. The purse seiners deploy FADs in the conventional drifting gillnet fishing ground and since that time most drifting gillnet fleets move to the inshore waters.

\section{Fish Size}

The first maturity size has been stated as $35 \mathrm{~cm}$ $(\mathrm{FL})$, when the fish is two years old (Rodriguez-Roda, 1983 in Kahraman, 2010) that was in line with result of the research by Kahraman et al. (2010) which determined that sexually mature bullet tuna specimens were always well over $35 \mathrm{~cm}$ FL. Adults are principally caught in coastal waters and around islands (Anonymous., 2006). Base on the information of maturity size as mentioned above, so that $<50 \%$ of bullet tuna caught by drifting gillnet in April was juvenile fish, whilst in August and December mostly of bullet tuna caught at matured size.

Maximum length of frigate tuna (unsexed) reaches $65 \mathrm{~cm}$ (CayrP, 1993). According to Jude et al. (2002) that males and females frigate tuna were found to attain maturity at slightly different length. Males 
attained maturity at slightly smaller length than females. Males attain maturity at $30.8 \mathrm{~cm}$ while females at $32.8 \mathrm{~cm}$. If assumed that all frigate tunas catch were females with length at first matured $\left(\mathrm{L}_{\mathrm{m}}\right)$ $32.8 \mathrm{~cm}$, so that the number of matured frigate tuna caught by drifting gillnet was reached $61.3 \%$ in April, whilst in August and December were $69.6 \%$ and $74.6 \%$ respectively. It means that mostly of frigate tuna caught by drifting gillnet at matured size.

\section{COUCLUSION}

Bullet and frigate tuna caught by drifting gillnet in Indian Ocean based at Cilacap Fishing Port as byproduct, accounted $0.4 \%$ and $1.6 \%$ of the total catch. The catch fluctuated between months and peak season experienced on December. The catch rate of both species bullet and frigate tuna decreased year by year since six past years, in 2011 the catch rate of bullet tuna $0.013 \mathrm{mt} /$ trip/vessel and frigate tuna was $0.054 \mathrm{mt} /$ trip/vessel. Both of species bullet and frigate tuna caught by drifting gillnet mostly as adult fish.

\section{ACKNOWLEDGMENT}

We wish thanks to Mr. Joko Riyanto (statistician of Cilacap Fishing Port) and Mr. Alif (enumerator in Cilacap Fishing Port) who provided the data. We would like also thanks to all of the drifting gillnet fishers based at Cilacap Fishing Port who helped during sampling activities, as well as Mr. Abram Barata who provides some literatures on frigate tuna.

\section{REFERENCES}

Anonymousymous. 2006. Compilation of information on neritic tuna species in the Indian Ocean. $A$ working paper, IOTC-2006-SC-INF11.

Anonymousymous. 2010. Summary of National Fisheries Statistic of Indonesia Year 2001-2009. DGCF, Ministry Marine Affairs and Fisheries of Republic Indonesia.
Cayré, P., J.B. Amon Kothias, T. Diouf \& J.M. Stretta, 1993. Biology of tuna. p. 147-244. In A. Fonteneau and J. Marcille (eds.) Resources, fishing and biology of the tropical tunas of the Eastern Central Atlantic. FAO Fish. Tech. Pap. 292. Rome, FAO. $354 \mathrm{p}$.

Figueiredo, J.L. de, A.P. dos Santos, N. Yamaguti, R.A. Bernardes \& C.L. Del Bianco RossiWongtschowski. 2002. Peixes da zona econômica exclusiva da Região Sudeste-Sul do Brasil: Levantamento com Rede de Meia-Água. SãoPaulo: Editora da Universidade de São Paulo; Imprensa Oficial do Estado, 242 p.

Herrera, M \& Lucia Pierre, 2009. Status of IOTC Databases For Neritic Tunas. IOTC-2009-WPDCS06.

Jude, D., N.Neethiselvan, P.Gopalakrishnan \& G.Sugumar, 2002. Gillnet selectivity studies for fishing frigate tuna, Auxis thazard Lecepede (Perciformes/Scombridae) in Thoothukkudi (Tuticorin) waters, southeast coast of India. Indian Journal of Marine Sciences. 31(4), p. 329-333.

Kahraman, A., D.Göktürk, E.R. Bozkurt, T. Akaylý, \& F.S Karakulak (2010). Some reproductive aspects of female bullet tuna, Auxis rochei(Risso), from the Turkish Mediterranean coasts. African Journal of Biotechnology. ISSN 1684-5315 C2010 Academic Journals. 9 (40): p. 6813-6818.

Widodo, A.A, F.Satria, L.Sadiyah \& J.Riyanto, 2011. Neritic tuna species caught by drifting gillnet in Indian Ocean based at Cilacap-Indonesia. The paper presented on the IOTC Working Party on Neritic Tuna, Chenai-India, 14-17 November 2011, IOTC-WPNT01-21. 